\title{
AGAMA DAN HAPPINESS
}

\author{
Uqbatul Khoir Rambe \\ Universitas Islam Negeri Sumatera Utara (UINSU) Medan \\ uqbatulkhoir@gmail.com
}

\begin{abstract}
Abstrak
Kebahagiaan adalah dambaan setiap orang, berbagaiupaya dilakukan manusia untuk mendapatkan kebahagiaan, salah satunya adalah dengan memeluk suatu agama. Tulisan ini merupakan library reseach dan deskriptif yang berupaya mendeskripsikan konsep agama-agama besar dunia tentang kebahagiaan, serta respon rasional dan sosial kemasyarakatan setiap agama tersebut.Dapat disimpulkan bahwa setiap agama mempunyai konsep kebahagiaan. Secara normatif setiap agama memberikan landasan kepada pemelukuntuk mendapatkan kebahagiaan. Secara rasionalitas para tokoh berupaya memberikan pencerahan kepada umatnyademi mencapai kebahagiaan. Adapun secara sosio empirik dinyatakan bahwa respon umat beragama terhadap kebahagiaan tersebut sangat beragam, dan keberagaman tersebut terjadi pada seluruh umat beragama.
\end{abstract}

Kata kunci: Agama, Konsep Kebahagiaan(Happiness)

\begin{abstract}
Happiness is everyone's dream, various efforts made by humans to get happiness, one of them is to embrace a religion. This paper uses the library research and descriptive method, which seeks to describe the concept of the world's major religions about happiness, as well as the rational and social response of each of these religions. It can be concluded that every religion has a concept of happiness. Normatively every religion provides a foundation for adherents to get happiness. Rationally, the figures try to give guidance to their people in order to achieve happiness. As for socio-empirically stated that the response of religious communities to happiness is very diverse, and that diversity occurs in all religious communities.
\end{abstract}

Keywords: Concept of Happines, Religion

\section{Pendahuluan}

Kebahagian dalam hidup merupakan impian bagi setiap manusia, yakni bahagia hakiki. Bahkan berbagai cara diupayakan demi meraihnya, baik halal maupun haram. Adapun salah satu media yang digunakan untuk mencapai kebahagian tersebut adalah agama, berbeda agama maka berbedalah konsep kebahagiaannya.

Agama di dunia menjadi suatu hal yang sangat sensitif, kajiannya pun sangat diminati para ilmuan dan peneliti. Begitu halnya di Indonesia agama memiliki peran penting. Indonesia mengakuai adanya agama yang berbeda, namun prinsipnya berbeda-beda tapi tetap satu. Dengan 
keanekaragaman agama yang ada, dan keharmonisan hidup yang saling berbahagia, tulisan ini berupaya menelisik bahagia dalam pandangan berbagai agama besar dunia, yakni mendeskripsikan pandangan agama Islam, Kristen, Bunda dan Hindu mengenai bahagia yang menjadi tujuan setiap manusia.

\section{Pengertian Happines}

Kata bappines berasal dari kata bappy yang berarti keberuntungan, kemujurn, keriangankepuasan, kegembiraan dan lain sebagainya. Adapun kata happines yang berarti kebahagiaan adalah rasa damai, bahagia dan sejahtera yang bersifat temporer dan relatif, dengan tanda perasaan suka yang mendominasi, kemudian berkembang dari kepuasan sampai pada kesenangan hidup yang dirasakan secara mendalam, intens dan terus menerus, serta berkepanjangan (1994: 75).

Kata tersebut dalam bahasa indonesia diartikan dengan kata kebahagiaan atau bahagia. Secara etimologi kata kebahagiaan atau bahagia mengandung arti seuatu keadaan dalam kesenangan,keadaan dalam ketenteraman dan terbebas dari hall-hal yang menyulitkan dan menyusahkan. Maka makna kebahagiaan tersebut mempunyai makna rasa bahagia, rasa senang dan rasa tentram dalam hidup baik lahir maupun batin (Philips, 2001 : 365). Di dalam bahasa arab sinonim dari kata bahagia atau kebahagiaan itu adalah kata as-sa'adah. Pada kamus alMunawwir kata as-sa'adahtersebut mengandung arti bahagia dan mujur (Munwwir, 1997 : 632).

Happiness secara terminologis memiliki banyak pendapat, baik dari agamawan, psikolog dan filosof. Seperti halnya al-Barmaki menjelaskan bahwa yang dimaksud dengan bahagia itu ialah orang yang baik perbuatannya, kuat ingatannya, bijaksana akalnya,serta sabar dan tenang dalam menggapai maksud dan tujuannya. Adapun Al-Ghazali bahagia itu adalah suatu kenikmatan yang hakiki yang apabila manusia mampu mengingat dan mengenang Allah SWT selalu (Hamka, 1961 : 25) Sedangkan Ibnu Miskaway berpendapat bahwa kebahagiaan itu merupakan perpaduan antara kebahagiaan ruhaniyah dengan kebahagiaan akhlakiyah (1990 : 100). Pendapat lain seperti Ibnu Hajar al-Askolani menjelaskan bahwa kebahagiaan itu adalah paham akan Allah (Athaillah, 1995 : 13). Adapun Ibnu Qayyim menyatakan bahwa seseorang dapat dikatakan bahagia apabila ia mempunyai tiga indikator, yaitu; 1. Memiliki cahaya hikmah 2. Beruruk sangka pada diri sendiri 3. Mampu membedakan antara nikmat dan ujian Allah.

Di kalangan Filosof seperti Aris Tippus berpikiran sesungguhnya kebahagiaan merupakan sebahagian daripada kesenangan. Sedangkan kesenangan itu sendiri adalah tujuan. Maka sesungguhnya menurut Aris Tippus suatu kebahagiaan akan digapai bila seseorang sena, 
karena kebahagian itu berada di dalam kesenangan (Save, 2006 : 328). Dalam defenisi yang dikemukakan oleh Aristoteles, menurutnya kebahagiaan itu muncul apabila seseorang itu telah sampai kepada berprilaku baik, bukan suatu perbuatan yang timbul dari emosi yang temporer(perasaan baik yang datang dan pergi), akan tetapi ia merupakan prilaku manusia yang sempurna dan bernilai (Franklin, 2010 : 19). Sedangkan Sokrates menilai kebahagiaan itu adalah kondisi obyektif, dimana seseorang telah mampu melepaskan diri dari subjektifitasnya (Save, $2006: 241)$.

Di kalangan intelektual muslim Indonesia seperti Prof. Syahrin mengatakan bahwa kebahagiaan itu adalah terjalinnya hubungan horizontal-antropologis dan vertical transendental teosentris. Hal tersebut diwujudkan dalam bentuk iman dan amal yang dilakukan secara bersamaan, yang hasilnya menghantarkan manusia pada sifat kona'ah, yaitu mensyukuri apa saja yang diberikan Allah (Syahrin, 2015 : 347).

Sedangkan menurut Komaruddin Hidayatdalam bukunya Psikologi Kebahagiaan bahwa kebahagiaan tersebut bertingkat-tingkat. Tingkatan tersebut adalah:

1. Tingkatan jasadi. Kebahagiaan disini menyangkut kebahagiaan fisik seperti makan, minum, seks, rasa aman dan lain-lain.

2. Tingkatan kebahagiaan intelektual (Intelektual Happines). Kebahagiaan ini berada di dalam jiwa manusia. Kebahagiaan pada bidang ini lebih abadi bila dibandingkan dengan kebahagiaan fisik yang bersifat cepat berakhir antiklimaksnya.

3. Moral Happines, yaitu kebahagiaan yang didapatkan manakala menolong orang lain.

4. Spritual Happines. Kebahagiaan ini adalah kebahagiaan tertinggi yang diperoleh manusia. Pada tarap ini ruh dan nur yang ada di dalam diri manusia telah mengarah kepada mencintai Tuhan (Komaruddin, 2015 : 100).

\section{Konsepsi Agama-Agama Tentang Kebahagiaan}

Bagian ini dipaparkan konsepsi agama-agama tentang kebahagiaan, yakni :

1. Konsepsi agama Islam

Secara etimologi kata happines diterjemahkan ke dalam bahasa arab sebagai mana yang disebutkan di atas adalah kata as-sa'adah. Kata tersebut ketika dirujuk kepada Kitab Suci alQur'an tidak didapatkan. Yang ada adalah kata sa'iidun pada surah hud ayat 105 dan kata su'idu (fi'lun madin majbul) pada surah yang sama ayat 108 (Baqi, tt : 444). 
Pada ayat 105 ayat tersebut berbunyi yang artinya:

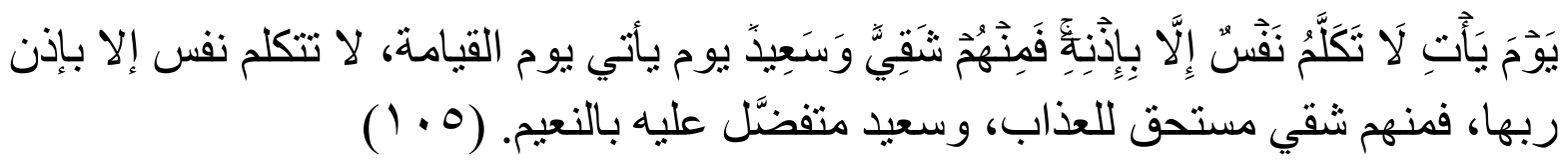

"Ketika hari itu datang, tidak seorangpun berbicara,kecuali dengan izin-Nya; maka di antara mereka ada yang sengsara dan ada yang bahagia".

Sedangkan pada ayat 108, artinya:

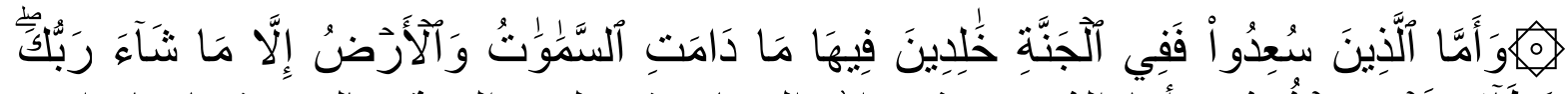

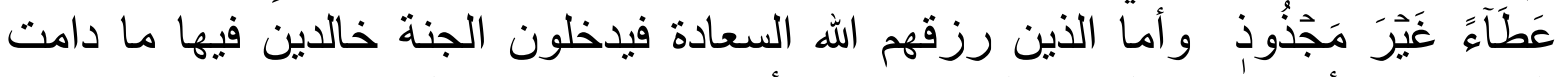
السموات و الأرض، إلا الفريق الذي شاء الله تأخيره، و هم عصاة الموحدين، فإنهم يبقون في النار فترة من الزمن، ثم يخرجون منها إلى الجنة بمشيئة الله ورحمته، ويعطي ربك الك هؤلاء

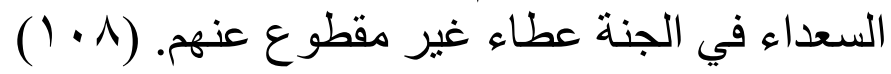

"Dan adapun orang-orang yang berbahagia, maka (tempatnya) di dalam surga; mereka kekeal di dalamnya selama ada langit dan bumi, kecuali jika Tuban-mu menghendaki (yang lain), sebagai karunia yang tidak ada putus-putusnya."

Ada hal menarik dari dua ayat yang dikemukakan di atas bahwa ke-dua ayat tersebut berbicara dalam konteks kebahagiaan akhirat. Pada ayat 105 tentang ketika hari akhirat itu mau datang maka ada dua golongan manusia; yaitu satu kelompok sedih dan yang satu kelompok lagi gembira. Pada ayat ini terlihat bahwa sesungguhnya azab itu belum datang, tapi telah membuat rasa sedih dan bahagia. Maka telihat makna bahagia tersebut adalah lawan daripada kesedihan. Pada ayat 108, konotasi bahagia tersebut sama dengan ayat 105, karena ayat tersebut merupakan sambungan dari ayat 105.

Jadi bila di lihat secara normatif dari sudut pandang agama islam bahwa kata bahagia tersebut ada secara normatif. Dari sekian banyak teks Qur'an ternyata hanya dua ayat yang berbicara tentang kata bahagia dan itupun konteksnya di akhirat, bukan di dunia. Kebahagiaan yang terkonfirmasi dari ayat tersebut adalah kebahagiaan rohaniyah yang merupakan lawan daripada kesedihan.

Secara rasional banyak sekali pendapat para ulama islam yang berbicara mengenai kebahagiaan ini baik dari mufassir, pemikir, filosof, Sufi, dan pemerhati adab maupun akhlak. Dari sekian banyak orang tersebut yang paling luas membahas ini menurut penulis adalah Imam al-Gozali. Di dalam bukunya ihya, ia menjelaskan bahwa kebahagiaan itu ada lima tingkatan, yaitu: 
a. Kebahagiaan akhirat. Kebahagiaan ini merupakan kebahagiaan tinggi da kekal pada posisi ini tidak ada lagi kesedihan dan kemiskinan sama sekali. yang tersisa hanya sukacita dan kenikmatan. Untuk menggapai kebahagiaan ini tidak ada upaya manusia, kebahagiaan ini di dapat hanya berkat izin Allah swt.

b. Kebahagiaan akal budi. Kebahagiaan ini di peroleh melalui kesempurnaan akal dengan ilmu pengetahuan.Pada taraf ini manusia tersebut telah sampai pada tingkat wara'(tidak perduli kenikmatan duniawi). Manusianya sangat takut kepada kesalahan dan sangat cinta pada kebenaran

c. Kebahagiaan jasmani. Kebahagiaan ini bertumpu pada kebahagiaan karna memperoleh tubuh yang sehat badan yang kuat wajah yang tampan, serta panjang umur

d. Kebahagiaan non jasmani. Kebahagiaan ini berpusat pada melimpahnya kekayaan materil, keharmonisan dalam keluarga, dan status sosial yang terhormat serta generasi yang membanggakan.

e. Kebahagiaan atas mengalirnya petunjuk dari Allah. Kebahagiaan ini merupakan karunia agung berbentuk pengawasan, penjagaan, pembimbingan dan pertolongan dari Allah swt (Hamka : 43).

Menurut al-Gozali kebahagiaan tertinggi hanya dapat di peroleh lewat ketaqwaan kepada Allah serta kekuatan diri untuk mengendalikan hawa nafsu, yaitu dengan cara menutup hubungan bathin terhadap segala sesuatu yang bersifat profan dengan upaya menghindarkan diri daritipu daya dan kepalsuan dunia, lalu mengarahkan dan meyerahkan segenap jiwa dan raga terhadap Allah swt (Al-Gozali, 1986 : 49) sehingga mencapai ma'rifatullah. Selanjutnya ia menjelaskan segala kebahagiaan dan kenikmatan itu berlandaskan pada tabiatnya, mata kenikmatannya dengan melihat keindahan, telinga kenikmatannya dengan mendengar suara yang merdu dan selanjutnya tergantung kepada personal setiap pribadi manusia. Adapun kebahagiaan hati adalah saat bertemu dengan allah swt (Hamka : 25).

Adapun pada tataran sosio empiris adalah kenyataan yang terjadi pada masyarakat umat islam kebanyakan. Untuk mengerti hal tersebut tentunya perlu penelitian yang mendalam dengan menetapkan terlebih dahulu apa yang menjadi ukuran dari kebahagiaan tersebut. Seumpama harta yang menjadi ukuran kebahagiaan tersebut maka tidak semua umat islam miskin, bahkan banya negara-negara islam yag superkaya. Apabila batin yang menjadi ukurannya maka setiap orang mempunyai perasaan yang berbeda-beda, dan sangat tergantung pada kondisi masing-masing. 
Oleh karena itu kebahagiaan umat islam secara sosio empirik sangat susah untuk menyimpulkannya, karena selain kebahagiaan itu sangat bersifat personal, juga ia sangat tergantung pada lingkungan yang melingkupinya.

\section{Kebahagiaan menurut agama Kristen}

Secara normatif dorongan agama kristen untuk memperoleh kebahagiaan tertuang dalam al-Kitab, Majmur 1:1, yang artinya : Berbahagialah orang yang tidak berjalan menurut nasibat orang fasik, yang tidak berdiri di jalan orang berdosa, dan yang tidak duduk dalam kumpulan pencemooh,"

Secara rasional untuk menjelaskan pemikiran keristen tentang kebahagiaan danhubungannya dengan agama nampaknya pemikiran Thomas Aquinas sangat layak untuk dikemukakan. Selain seorang filosof ia juga seorang agamawan kristen yang taat, oleh karena itu pikirannyapun selalu dirasakan adanya nuansa spritual yang kental tatkala ia membahas suatu persoalan, semisal masalah kebahagiaan misalnya. Menurutnya untuk meraih kebahagiaan manusia harus mencarinya secara total. Secara total yang ia maksudkan adalah kebahagiaan yang dirasakan jiwa dan raga secara bersama-sama. Kebahagiaan itu akan dinamakan membahagiakan jika menyentuh tubuh dan jiwa manusia sekaligus Bertens, 1998 : 38).

Pemahaman seperti itu dimaknainya berlandaskan eksistenti manusia yang akan dinamakan manusia bila ada tunuh dan jiwa. Ia mengakui akan eksistensi tubuh yang bisa meraih suatu kebahagiaan. Tubuh sebagai penerima segala yang dapat dirasakan dan yang dialami dapat menerima atau menolak obyek-obyek tertentu yang mendatangkan kebahagiaan atau yang menyakitkan tubuh. Ketertarikan dan penolakan ini merupakan bentuk awal dari kemampuna manusia untuk mencintai yang mendatangkan kebahagiaan dan membenci yang tidak menyenangkan (Ohoitimur, 2004 : 148). Namun objek-objek yang mendatangkan kebahagiaan itu seperti uang, harta, makanan dan minuman, kenikamatan indrawi, kekuasaan serta gengsi akan memacu manusia untuk bergerak terus tiada henti demi memuaskan keinginan tubuh tersebut (Mondin, $1991: 350$.

Oleh karena itu menurut Thomas Aquinas kebahagiaan yang berlandaskan pada tubuh tidaklah cukup karena kebahagiaan yang diraih tubuh bersifat terbatas (Weis, 2000 : 51). Argumen yang dibangunya adalah bahwa keinginan yang ada dalam tubuh itu cenderung untuk segera didapatkan dan dipuaskan. Untuk itu dubutuhkan keputusan untuk menjatuhkan pada kehendak tersebut. Sayangnya semua keputusan kehendak belum tentu benar dan mendatangkan kebahagiaan. Disinilah menurutnya kegunaan intelek manusia. Namun demikian 
menurutnya para intelek itu masih diselubungi oleh keterbatasan sehingga belum tentu bisa untuk memberikan kebahagiaan yang sebenarnya (Ohoitimur : 149).

Kebahagiaan yang sesungguhnya, yang sanggup diraih oleh manusia secara personal maupun secara kolektif tidaklah terletak pada suatu benda, nilai atau materi tertentu, namun ia terletak pada saat manusia itu sanggup untuk mencapai kepada penglihatan atas (Harun, 1980 : 12).Dalam pandangannya, proses pencarian kebahagian itu bermula dari benda-benda, lalu kepada nilai-nilai lahiriah, selanjutnya kepada nilai-nilai yang lebih agung, sehingga sampai kepada puncak kebahagiaan tersebut yaitu ketika menyaksikan (Frederick, 1950, 112).Kebahagiaan yang seperti itulah menurut Thomas Aquinas merupakan hal yang mungkin untuk digapai manusia yang akan terwujud secara definitif setelah manusia mati, yaitu suatu kehidupan abadi dimana manusia tertambat secara kuat kepada Tuhan dan tidak akan terlepaskan (Weis : 52).

Menurut Thomas, sebagai orang beriman janganlah manusia mencari kebahagiaan pada sesuatu yang bersifat duniawi tetapi harus dicari lebih tinggi karena hanya ada satu yang sempurna, tertinggi. Dialah Tuhan, dan hanya Dia-lah yang dapat membahagiakan manusia sepenuh-penuhnya (Weis : 72).

3. Kebahagiaan menurut agama Budha

Secara normatif Budha menjelaskan melalui sabda-sabda-Nya tentang jalan manusia untuk meraih kebahagiaan.

Di antara sabda-sabdanya itu adalah;

"Sukham vatatassa na hoti kinci : Sunggub berbahagia orang yang tidak mempunyai sesuatu yang dikhawatirkan"

Pada sabda lain sang Budha mengatakan;

"Cittam dantam sukhavaham: Pikiran yang telah terlatih memberikan kebahagiaan".

Menurut Pdt. Dharma Mitra (Peter Lim) pada kitab suci Bojjhanga Sutta, terdapat 7 jalan yang dapat ditempuh manusia agar menperoleh kebahagiaan, lalu terhindar dari penderitaan. Ke-7 jalan itu ialah:

a. Sati (perhatian benar)

Menurut Pdt. Dharma Mitra (Peter Lim) di dalam hidupnya manusia harus mempunyai perhatian yang baik di dalam semua gerak dan langkah kehidupannya. Segala perbuatan, baik pikiran, perkataan dan tindakan jasmani harus direnungkan 
terlebih dahulu akan dampak yang akan ditimbulkan oleh perbuatan tersebut. Menurutnya harus direnungkan terlebih dahulu akan dampak dari suatu perbuatan. Jika dari hasil renungan tersebut dampak kebahagiaan yang lebih dominan baru dilaksanakan. Akan tetapi bila dampak negatifnya lebih banyak, maka pekerjaan tersebut harus ditinggalkan.

b. Dhammavicaya (Meneliti dan Menyelidiki Kebenaran).

Menurut Pdt. Dharma Mitra (Peter Lim) semua urusan haruslah diteliti dan diselidiki terlebih dahulu kebenarannya, bahkan menurutnya ajaran Budha sekalipun. Menurutnya ajaran Buddha Dharma yang diajarkan oleh Sang Buddha, bukanlah untuk dipercayai begitu saja, akan tetapi harus diteliti terlebih dahulu kebenarannya. Menurutnya selama 45 tahun Sang Buddha menyebarkan ajaran-Nya, Ia tidak pernah mengatakan bahwa ajaran-Nya-lah yang paling benar bila dibandingkan dengan ajaran agama-agama lainnya. Budha selalu menngajarkan betapa perlunya untuk memahami lalu meneliti kemudian menyeelidiki segala sesuatuterlebih dahulu, sebelum suatu itu dijadikan sebagai pedoman hidup, agar kelak hari tidak menbuat kepanatikan dan kemunafikan serta ke-tidak toleransian.

c. Viriya ( Semangat).

Menurut Pdt. Dharma Mitra (Peter Lim) semangat sangatlah penting di dalam hidup dan kehidupan manusia. Ia mengatakan bahwa semangat itu bisa diibaratkan bagaikan api, yang menghangatkan suasana, agar tidak menjadi kaku dan monoton. Ciri khas orang sukses dan bahagia menurutnya adalah orang yang selalu semangat di dalam setiap derap langkahnya, baik dalam kondisi menyenangkan (berhasil) maupun dalam kondisi menyedihkan (gagal). Menurutnya manusia yang semangat adalah manusia yang senantiasa kreatif, inovatif dan mampu memotivasi dirinya sendiri.

d. Piti (Kegiuran / Kegembiraan).

Menurut Pdt. Dharma Mitra (Peter Lim) Sang Buddha sangat menekankan akan betapa pentingnya memikirkan hidup untuk saat ini dan jangan memikirkan apa yang telah berlalu atau apa yangakan terjadi di masa yang akan datang. Apa yang diperbuat saat ini, itulah yang menentukan corak kehidupan dimasa yang akan datang, dan apa yang telah diperbuat masa lalu adalah apa yang dirasakan saat ini. Oleh karena itu, sangat dianjurkan oleh Budha supaya manusia berbuat kebajikan sedini mungkin 
(disaat ini) dan sebanyak - banyaknya, agar terbebas dari jeratan derita dan meraih kebahagiaan yang sejati.

e. Passadhi (Jasmani Dan Bathin Relax)

Menurut Pdt. Dharma Mitra (Peter Lim) manusia harus pandai mengatur waktu, jangan sampai manusia diperbudak oleh waktu sehingga manusia kurang memperhatikan jasmaniah dan rohaniahnya. Jasmani dan rohaniyah menurutnya harus diberi waktu untuk relaxs. Orang yang terbelenggu oleh waktu, lebih cenderung banyak mengalami kekecewaan dan prustasi. Raga dan batin yang difungsikan secara maksimal namun tidak diberikan masa relaxs, dapat mengakibatkan sakin dan gangguan mental, serta berbagai macam penyakit lainnya.

f. Samadhi (Konsentrasi).

Menurut Pdt. Dharma Mitra (Peter Lim) samadhi (semacam tapa, meditasi. pen.) merupakan syarat wajib yang harus dilakoni supaya dapat terlepas dari penderitaan. Orang yang ber-samadi akan terhindar dariperbuatan-perbuatan yang tidak baik. Seseorang dapat terjatuh kepada tindakan yang nista dan tercela sperti membunuh, merampok, mecuri, memfitnah dan lain sebagainya dari hal-hal yang buruk dari perbuatan manusia. Hanya orang-oran yang kuat dalam samadi-nyalah yang akan mempunyai pertahanan dalam dirinya untuk menghindarkan diri dari berbagai macam perbuatan yang tidak benar tidak

g. Upekka (Keseimbangan Bathin).

Menurut Pdt. Dharma Mitra (Peter Lim) Upekkhamerupakan penuntun bagi manusia untuk berlaku adil dalam memutuskan suatu perkara dan permasalahan. Orang yang melakukan kesalahan harus diberikan hukuman, sebaliknya orang yang melakukan juga harus diberi ganjaran. Tidak boleh ada diskriminasi dan keberpihakan tatkala memutuskan persoalan, Saat ber-dana (beramal), seseorang harus memberikan dana (derma) kepada seriap orang dengan tanpa melihat latar belakang, agama, suku, aliran faham dan sebagainya.

Pendapat lain, Dalai Lama mengatakan bahwa kebahagiaan itu datang dari pihak lain, ketika manusia mengutamakan kesejahteraan sesama daripada kesenagan diri sendiri. Sebaliknya manusia itu akan mendapatkan kegelisahan, kesakitan dan prustasi ketika manusia mementingkan dirinya sendiri (Dalai, 2006 : 122).

4. Kebahagiaan menurut agama Hindu 
Ajaran normatif agama hindu mengenai kebahagiaan tertuang di dalam kitab Sarasamuscaya. Di dalam kitab tersebut dikatakan;

"Yan Paramarthanya, yan arthakama sadhyan, dharma juga lekasakena rumubun, niyata katemwaning artha kama mene tan paramartha wi katemwaning arthakama dening anasar sakeng dharma".

Artinya adalah: "kalau artha dan kama yang dituntut, maka seharusnya dharma dilakukan lebih dabulu, tak tersangsikan lagi, pasti akan diperoleh artha dan kama itu nanti, tidak akan ada artiny a jika artha dan kama itu diperoleb menyimpang dari dharma".

Dari petikan ayat kitab Sarasamuscayaitu dapat dipahami bahwa bahwa dharma wajib dilaksanakan oleh setiap orang. Apabila darma tersebut telah dilaksanakan dengan baik maka artha dan kamasecara otomatis akan didapatkan.

Pada ayat lain di dalam kitab Manu Sambita dikatakan :

"Weda Pramanakah sreya sadhanam dharmah"

Artinya: "Di dalam ajaran suci weda dharma dikatakan sebagai alat untuk mencapai kesempurnaan".

Bagi agama Hindu tujuan utama dari pada hidup manusia di dunia terdapat dalam kitab Catur Purusa Artha. Di dalam kitab tersebut terdapat empat tujuan untuk meraih kebahagiaan dunia dan akhirat. Ke-empatnya adalah:

a. Dharma yaitu ajaran-ajaran suci yang mengatur, memelihara atau menuntun umat manusia untuk mencapai kesejahteraan jasmani dan ruhani. Dharma juga berarti agama dan kewajiban, kemuliaan, kebajikan serta kebenaran. Dharma merupakan pegangan hidup umat Hindu yang wajib dilaksanakan pada setiap aspek kehidupan, termasuk dalam berpikir, bertindak pada masyarakat dan lingkungan.

b. Artha yaitu harta benda atau kekayaan/uang. Menurut pemahaman agama Hindu tanpa adanya artha/uang/materi yang mencukupi maka kehidupan akan membuat kehidupan menjadi sulit. Kesulitan hidup akan membuat orang cenderung untuk bertindak adharma, seperti melakukan pencopetan, pencurian, perampokan , penipuan, berbohong dan lain sebagainya, Pada agama Hindu berusaha untuk memiliki artha sangat dianjurkan, yang penting artha tersebut harus didapatkan lewat dharma, dan diper gunakan untuk urusan dharma pula. Agama Hindu sangat menekankan bahwa artha sesungguhnya tidaklah menjadi tujuan utama, namun artha 
hanya sebatas sarana untuk meraih maksud dan tujuan. Dalam agama Hindu artha yang dimiliki harus dipergunakan pada tiga hal, yaitu :

1. Sadhana ri kasiddaning dharma; artinya bahwa artha dipergunakan untuk dharma. Contoh hal ini ialah perbuatan baik yang dilakukan manusia sebagai sebagai kewajiban dalam melaksanakan Panca Yadnya,

2. Sadhana ri kasiddaning kama; adalah bermakna Artha dipergunakan untuk mencukupi kama. Contoh hal ini ialah kegiatan pada bidang seperti kesenian, olah raga, dan rekreasi serta hal lainnya.

3. Sadhana ri kasiddaning artha; adalah Artha yang dipergunakan untuk memperoleh kekayaan dalam bidang harta benda. Contoh daripada hal ini adalah berbagai macam kegiatan yang dapat menghasilkan sesuatu, layaknya seperti kegiatan ekonomi dan hal sebagainya.

Manfaat daripada harta dan kekayaan itu selain untuk kepentingan pribadi juga sebagian harus disedekahkan. Sebab pahala dari pada bersedekah yang dilakukan secara tulus dan ikhlas tida dapat dihingga nilainya.Pada agama Hindu berulang kali dijelaskan bahwa sanya kekayaan tersebut tidak sedikitpun dibawa mati. Perbuatan baik buruk seseorang merupakan penuntun kepada akhirat yang bahagia atau sengsara. Oleh karena itu berbuat baik seperti bersedekah hendaklah digalakkan yang merupakan tanda bakti pada agama sebagai dharma. Dengan demikianlah maka harta bisa bernilai di sisi Yang Maha Kuasa.

c. Kama:adalah nafsu atau hasrat yang bisa memberi kepuasan atau kesejahteraan hidup manusia. Kepuasan atau kenikmatan tersebut memang merupakan salah satu tujuan atau kebutuhan manusia, karena manusia mempunyai dasendriya atau 10 indriya. Kesepuluh indriya tersebut menyebabkan manusia berbuat sesuatu. Indriya sering diumpamakan seperti kuda liar, kalau dapat dikendalikan akan merupakan kekuatan yang luar biasa. Kama atau kesenangan menurut ajaran agama tidak akan ada artinya jika diperoleh menyimpang dari dharma. Karenanya dharma menduduki tempat di atas dari kama dan menjadi pedoman didalam pencapaian kama.

d. Moksa : yang merupakan tujuan terakhir dan tertinggi dari manusia. Moksa disebut juga mukti atau nirwana yang berarti kebebasan atau kelepasan. Maksudnya adalah suatu kebahagiaan dimana atma dapat lepas dari pengaruh maya dan ikatan subha asubha karma, serta bersatu kembali dengan asalnya yaitu Brahman. Pada hakekatnya 
setiap manusia mendambakan kebahagiaan yang kekal abadi (sat cit ananda), namun kebahagiaan seperti itu tak kunjung dirasakan karena menurut ajaran agama Hindu kebahagiaan yang sejati atau kebahagiaan yang kekal abadi itu cuma diperoleh lewat penyatuan dengan Yang Maha Kuasa (Ida Sang Hyang Widhi). Kebahagiaan yang yang seperti itulah yang dinaman dengan moksa.

Pendapat lain dikemukakan oleh Patanjali seorang akademisi dan pemikir Hindu terkenal di India, Menurutnya Yoga merupakan warisan agama hindu yang murni, yang silakukan uleh ummat hindu untuk memperoleh kebahagiaan (Arlene, tt : 18).

\section{Respon Sosial Empiris}

Respon setiap umat beragama terhadap kebahagiaan tersebut menurut peneliti tidak jauh berbeda pada setiap pemeluk agama-agama. Secara tekstual maupun konseptual telah disebutkan di atas bahwa semua agama mempunyai patron yang jelas terhadap kebahagiaan tersebut. Adapun secara sosial empiris penulis kira masing-masing umat beragama mempunyai keinginan yang sama untuk memperoleh kebahagiaan pada semua tingkatan, dari kebahagiaan jasadi, kebahagiaan intelektual, kebahagiaan moral serta kebahagiaan spritual sebagaimana yang disebut KomaruddinHidayat.

Persoalannya mungkin pada intensitas masing-masing umat beragama. Namun bila pada persoalan ini sangat tergantung kepada masing-masing individu pada setiap umat beragama.

\section{Hubungan agama dan kebahagiaan}

Peroalan utama dalam pembahasan ini adalah apakah agama dapat memberikan kebahagiaan kepada ummatnya?. Banyak sekali pakar yang menyelidiki persoalan ini terutama mereka yang berkecimpung di bidang psicologi seperti Robert D Putnam dan Robert F Inglehart. Dalam suatu penelitian yang mereka lakukan, mereka mendapatkan kesimpulan bahwa orang-orang yang beragama ataupun orang yang berhubungan dengan agama jauh lebih bahagia dibandingkan dengan orang yang tidak pertalian atau orang-orang yang tidak memiliki persinggungan pada suatu agama. Penelitian seperti ini telah dilakukan berulang-ulang, namun kesimpulannya tetap sama dimana orang yang berkeyakinan pada agama atau orang yang taat pada agamanya tetap lebih tenang dan bahagia bila dibandingkan dengan orang yang tidak mempunyai agama dan keyakinan serta orang yang tidak ada konektifitas pada agama tertentu.

Menurut Robert F Inglehart salah satu bukti bahwa agama dapat memberikan kebahagiaan kepada umatnya adalah bertahannya agama hingga ribuan tahun meskipun 
mendapat gempuran dari zaman dan rasionalitas yang mencoba menihilkan agama dari masyarakat pemeluknya. Agama selalu lebih dapat memberikan dan menjelaskan arti kehidupan (meaning of life) bila dibandingkan dengan pesona-pesona lain yang datang dari luar agama.

Penelitian yang dilakukan oleh Robert F Inglehart tidak berhenti sampai disitu, akan tetapi ia mengexplorasi lebih jauh menyangkut sisi apa dari agama yang membuat pemeluknya lebih bahagia. Disamping itu ia juga meneliti mengapa pada suatu negara yang berlandaskan agama seperti Syiria dan Afganistan justru pemeluknya merasa kurang bahagia.

Dari survei yang ia lakukan bersama bersama General Sosial Survei dengan responden sebanyak 20.000 orang, dengan masa penelitian selama 18 tahun dari tahun 1972-1990, dengan kategori sangat bahagia, bahagia dan kurang bahagia.

Kesimpulan yang mereka dapatkan adalah bahwa sisi agama yang menyebabkan penganutnya lebih bahagia adalah sosial network antar penganut agama tersebut. Agama lebih mampu memberikan sosial network antar penganutnya yang lebih meaning ful dan akrab. Dari sosial network tersebut membuat penganut agama lebih saling berbagi, saling perduli dan saling membantu. Kata kunci yang ada dalam agama tersebut adalah sosial support, dimana orangorang yang beragama merasa saling membantu, saling mengasihi selaku saudara seiman. Sosial support agama itu jauh lebih kuat dibandingkan dengan sosial support yang ada selainnya seperti budaya misalnya.

Pada persoalan lain dimana suatu negara yang berazaskan agama namun penganut agama di negara tersebut (seperti Syiria dan Afganistan) merasa tidak bahagia. Hal tersebut menurut penelitian mereka disebabkan oleh teror dan intoleransi, kekejaman, kebengisan serta kedholiman yang berlaku pada negara tersebut. Pemerintahan yang sewenag-wenang akan membuat penganut suatu agama tidak akan bahagia meskipun negara tempat mereka tinggal adalah negara agama. Dalam kesimpulan akhir mereka menandaskan bahwa lingkungan yang kondusif sangat berpengaruh pada suatu kebahagiaan.

Persoalan lain menyangkut hal ini adalah dapatkah seseorang bahgia tanpa agama, atau dalam bahasa lain adakah yang bisa membuat seseeorang bahagia di luar agama. Untuk menjawab hal ini ada penelitian yang dilakukan oleh Martin Seligman (2011 : 237). Menurutnya ada 5 elemen yang dapat membawa manusia kepada kebahagiaan di luar agama. Kelima element tersebut ia singkat dengan kata "PERMA". PERMA tersebut artinya adalah: 
$\mathrm{P}=\quad$ Positif Emotion. Maksudnya adalah manusia harus selalu berfikir fositif dan selalu optimis dalam menghadapi persoalan dunia.

$\mathrm{E}=$ Enggagement. Maksudnya manusia harus selalu menyibukkan diridengan pekerjaan yang berarti.

$\mathrm{R}=\quad$ Relationship. Maksudnya adalah banyak menjalin hubungan dengan orang lain.

$\mathrm{M}=\quad$ Meaning. Maksudnya adalah mencari arti hidup di bumi Tuhan ini.

$A=\quad$ Accomplithments. Maksudnya adalah manusia harus mempunyai ambisi dan tujuan yang jelas dalam hidupnya.

\section{Penutup}

Berdasarkan pada penjelasan di atas dapat disimpulkan bahwa setiap agama mempunyai respon terhadap kebahagiaan tersebut. Secara normatif masing-masing agama memberikan landasan kepada pemeluknya untuk mendapatkan kebahagiaan.Demikian juga halnya bila dilihat rasionalitas penganut agama masing-masing. Para tokoh agama dan masing-masing intelektualnya memberikan pencerahan pada massanya/ umatnya untuk mendapatkan kebahagiaan. Tokoh-tokoh tersebut terlihat sangat gigih mengurai dan menampakkan jalan untuk meraih kebahagiaan yang dijanjikan agama masing-masing.Sedangkan secara sosio empirik penulis duga secara umum respon umat beragama terhadap kebahagiaan tersebut sangat beragam. Keberagaman tersebut terjadi pada seluruh umat beragama.

\section{Daftar Pustaka}

Bagun, Save M.(2006). Kamus Besar Ilmu Pengetahuan, edisi II, Cet. Ke-5 (Jakarta: Lembaga Kajian Kebudayaan Nusantara.

Baqi, Muhammad Fuad Abdul. Tt. Al-Mu'jam Al-Mufahros Li Alfazd Al-Qur'an, Indonesia: Maktabah Wahlan.

Bertens, K. (1998).Ringkasan Sejarah Filsafat, cet. Ke-15, Yokyakarta: Kanisius.

Franklin, Samuel S. (2010). The Psycology of Happiness: A Good Human Life, Ney York: Cambridge University Press.

Al-Gozali. (1986).Al-Munqidh Min Ad-Dholal, Pembebas Dari Kesesatan, Gersik: Bintang Pelajar.

Hadiwijono, Harun.(1980). Sari Sejarah Filsafat Barat I, Yokyakarta: Kanisius.

Hamka. (1961).Tasauf Modern, Jakarta: Djaja Murni. 
Harahap, Syahrin. (2015).Islam \& Moderenitas, Jakarta, PT.Fajar Interpratama Mandiri.

Hidayat, Komaruddin.(2015). Psikologi Kebahagiaan, Merawat Bahagia Tiada Akhir, ( Jakarta: Pt. Mizan Publikasi.

Lama, Y. M. (2006). Dalai Lama XIV, Kedamaian Batin, Judul Asli: The Little Book Of Inner Peace, Alih bahasa: Wahib Winoto, Jakarta: Dian Darma.

Mayer, Frederick. (1950). A History of Ancient of Mediavel Philosphy. New York: American Book Company.

Miskawai, Ibnu. (1990).Menuju Kesempurnaan Akblak; Buku Dars Pertama Tentang Filsafat Etika, Alih Bahasa Helmi Hidayat, Bandung; Mizan.

Al-Munawwir, Ahmad Warson. (1997).Kamus Al-Munawwir, Yogyakarta,Pustaka Progresif.

Mondin, Batista. (1991). A. History of Medieval Philosophy. Banglore: Theological Publication on India.

Morehead, Philip D. (2001).The New American Webster Dictionary,4th Edition, (New york : signet book.

Ohoitimur, J.(2004). Pokok-Pokok Sejarah Filsafat Masa Yunani Kuno Dan Abad Pertengahan, Traktat Kuliah STF- Seminrai Pineleng, Januari

Pusat Pembinaan Dan Pengembangan Bahasa. (1994).Kamus Besar Bahasa Indonesia, Jakarta: Balai Pustaka.

As-Sakandari, Ibnu Athaillah. (1995).Mutu Manikam, dari kitab Al-Hayyu, Terj. Jamaluddin Ahmad Al-Buny, Surabaya, Mutiara Ilmu.

Seligma, Martin E. P. (2011).Plowrish: A Visionary New Understanding Of Happines and Well Being,New York: Free Prees.

Suseno, Frans, Magnis.(1997) Tiga Belas Model Penedekatan Etika: Bunga Rampai teks-teks etika dari Plato- sampai dengan Nietache. Yokyakrta: Kanisius.

Uhl, Arlene Mattheus. (T.t). The Psychology Of Happines, New York, ALPHA.

Weis, P.A. Van Der. (2000). Filsuf-Filsuf Besar Tentang Manusia, Yokyakarta.

Weisheipl, James. A. (1993) “Thomas Aquinas." The Encyclopedia of Religion. vol 13 edited by Mirlea Eliade. London: Macmillan Publishing Company.

Yayasan Al-Risalah Al-Khoiriya. (T.t).Al-Qur'an Al-Karim, Depok: Sabiq. 